\title{
Dominant Factors Affecting Financial Distress: A Study on Miscellaneous Industry Sectors Listed in the Stock Exchange Years of 2014 to 2019 in Indonesia
}

\author{
Atang HERMAWAN ${ }^{1 *}$, Budi SEPTIAWAN ${ }^{2}$, Amira TRESNAWAT ${ }^{13}$ \\ 1,2,3Faculty of Economics and Business, Pasundan University, Indonesia. \\ Email: hermawanatang94@gmail.com", budi.septiawan@unpas.ac.id², amira.tresnawati@gmail.com³ \\ * Corresponding Author
}

\author{
Received: 23.07.2021 \\ Accepted: 05.10.2021 \\ Published: 01.12.2021 \\ DOI: 10.47750/QAS/22.185.09
}

\section{Abstract}

\begin{abstract}
This study aims to find empirical evidence regarding the relationship between liquidity, debt policy towards the company's financial distress. The population in this study were 29 mining companies listed on the Stock Exchange in 2014-2019, with the number of samples used was 17 companies. Data used was secondary data in the form of annual reports obtained from the IDX (www.sahamok.net). Testing in this study was carried out by ratio financial analysis. Statistical analysis of the study uses Structural Equation Modeling (SEM) with the alternative method is partial least square (PLS) use software SmartPLS version 3.0. The results show that Liquidity has been proven to have a significant positive effect on financial distress. The policy proved to have a significant negative effect on financial distress. The company's liquidity is proven to have a significant negative effect on debt policy. These results suggest that managers need to make some adjustments to the firm's liquidity level to meet their needs for debt and equity financing.
\end{abstract}

Keywords: Liquidity, Debt Policy, Financial Distress.

\section{Introduction}

This financial distress condition occurred before a bankruptcy and triggered the company's financial condition to worsen. Suppose the company's condition is approaching financial distress. In that case, the company's management usually decides to close all company activities, production activities, and other operational activities, before bankruptcy or what is often referred to as liquidation. To overcome this, the government will provide additional capital to companies experiencing financial distress. Thus, it is expected to restore a healthy financial condition of a company. One example of increasing capital is by issuing debt securities. As long as the amount of debt is under control and the company can pay it on time, this method will not cause additional problems. A company's financial problems can occur with a variety of causes, such as the company suffered losses continuously, selling unsold, natural disasters that make the company's assets is broken, the system of corporate governance are not good enough, or because the country's economy less stability that triggers the onset of the financial crisis. Long and Evenhouse (1989) in Emrinaldi (2007) found that the factors causing financial difficulties can be grouped into three parts, namely macroeconomic conditions, industrial and financial policies, the behavior of debtors and creditors. Brigham and Daves (2003) in Anggarini (2010) argue that financial difficulties occur due to a series of errors, inappropriate decision making, and interrelated. Weaknesses that can contribute directly or indirectly to management and the absence or lack of efforts to monitor conditions. The use of money is not following the needs.

According to Emrinaldi (2007), financial distress is a condition of financial difficulty starting from liquidity difficulties (short term) as an indication of the lightest financial difficulties, to a statement of bankruptcy which is the most severe financial difficulty. Liquidity is the ability of a company to pay financial obligations that must be repaid immediately (short term). Shortterm financial obligations that must be fulfilled immediately can be in the form of debts that will mature in the near term, wages for labor, debt for materials purchased, payments for electricity bills, drinking water needed in the production process, and so on. Liquid assets owned by the company can cover this obligation. Indahningrum and Handayani (2009) stated that one factor that influences the company's debt policy is institutional ownership. Institutional ownership is the ownership of company shares owned by institutions such as insurance companies, banks, investment companies, and other institutional ownership (Tarjo, 2008). The study results (Murni and Andriana, 2007. Indahningrum and Handayani, 2009) state that institutional ownership has a positive and significant influence on debt policy, which explains that the higher the level of institutional ownership of a company, the higher the amount of company debt.

Financial distress occurs when a company fails or is unable to satisfy the obligations to the creditor because it is experiencing shortages of funds. This unfavorable condition makes total liabilities greater than the total assets, and it cannot achieve the company's economic goals of profit. Financial distress occurs because the company is not able to manage and maintain the stability of financial performance. It is derived from its failure to promote the products. As a result, it causes the decline in sales values (Platt \& Platt, 2006). The declining sales results in decreasing operation incomes, and net loss for 
year. Losses incurred caused by capital deficiency is due to the decline of retained earning values so that the total equity as a whole is deficient. If this happens continuously, then the total liabilities will exceed the total assets owned by the company. This condition will trigger financial distress that eventually makes companies go bankrupt if they are not able to take appropriate measures.

An Indonesia study analyzes the role of corporate governance structure and financial ratios to the company's financial distress condition in the Indonesia Stock Exchange from years 2009 to 2011 (Hanifah, 2013). Results show that corporate governance, liquidity, profitability, and activity can predict the financial distress of manufacturing companies. Ownership of the board and the size of the board of directors as the proxies for corporate governance have negative and significant effect on the financial distress. The liquidity ratio projected by the current ratio has a significant negative effect on financial distress. Return on assets as a proxy for profitability ratio has negative and significant effect on financial distress. The activity ratio projected by total assets turn over has negative and significant effect on financial distress. Determining the debt policy, there is a liquidity factor that is taken into consideration by management. According to Ozkan (2001), liquidity affects debt policy because current assets provide convenience in repaying debt. The study results (Ramlall, 2009, Paydar and Bardai, 2012) prove that liquidity has a significant negative effect on debt policy; this result means that the more liquid a company is, the smaller the company's debt. On the other hand, different results are obtained (Sabir and Malik, 2012), finding that liquidity has a significant positive effect on debt policy; this result means that the more liquid a company is, the easier it is for companies to obtain debt from creditors.

Financial distress can be measured using financial ratios calculated from the financial statements of the company. Financial ratios show the company's financial position in a certain period, reflecting the company's performance in the corresponding period. An analysis of the company's financial ratios could provide information about the financial condition and provide a valuation process that aims to evaluate the financial position of the company's operational results in a certain period. The existence of a phenomenon related to financial distress that occurs in companies, especially various industrial sectors and also based on the results of previous studies that have not been consistent, so that researchers are interested in raising the title of the research "The Influence of Liquidity and Debt Policy on Financial Difficulties (Empirical Study of Manufacturing Companies in Multi-Industrial Sector on the IDX 2014-2019)".

\section{Literature Review}

\section{Effect of Liquidity on Debt Policy}

Liquidity is the main determinant for the company's survival, but is seen as two sides of a coin with profitability (Irawan and Faturohman, 2015). Liquidity is a tool to assess a company's financial performance by measuring its ability to meet its shortterm obligations. several liquidity variables in the study include, One of the liquidity ratios is the current ratio (CR), which compares current assets and current liabilities (Munawir, 2012: 72). According to Kasmir (2012:134), the current ratio is a ratio to measure the company's ability to pay short-term obligations or debts that are due immediately when billed in their entirety. In other words, how much current assets are available to cover short-term liabilities or debts that are due soon. Therefore, a high current ratio indicates an excess of cash or other current assets compared to what is needed now or a low level of liquidity than current assets and vice versa. Cash Ratio, according to Kasmir (2012:138), is a tool used to measure how much cash is available to pay debts. Availability of cash can be shown from the availability of cash or cash equivalents such as checking accounts or savings accounts in banks (which can be withdrawn at any time). Therefore, it can be said that this ratio shows the company's true ability to pay its short-term debts. Cash Turnover Ratio, according to Kasmir (2012: 140), is a cash turnover ratio that serves to measure the level of adequacy of the company's working capital needed to pay bills and finance sales. It means that this ratio is used to measure the level of cash available to pay bills (debts) and costs related to sales. To find working capital, subtract current assets from current liabilities. Working capital, in this sense, is said to be networking capital owned by the company. Every company needs to provide working capital; companies engaged in any field, both service companies and goods production companies, always need working capital to finance their business activities, hoping that the funds that have been issued can return to the company in a relatively short term. According to Haharap (2009:299), working capital is current assets minus current liabilities. Thus, this working capital is a measure of the security of the interests of short-term creditors. Working capital can also be thought of as funds available to invest in current assets or to pay the non-current debt.

H1: Liquidity affects the company's debt policy.

\section{Effect of Liquidity on Financial Distress}

Liquidity compares current assets with current liabilities. The greater the ratio of the company's current assets to its current liabilities, the higher its ability to pay off its short-term obligations (Sofyan, 2015: 301). According to Ni Wayan and Ni Ketut (2014) that the more liquid a company is, the more it avoids the threat of experiencing financial distress. Increasingly liquid companies will be able to pay off these debts and will not accumulate so that this can give a positive signal to outsiders that the company can pay off its current debts and avoid financial problems. Previous research conducted by Gusti and Ni Ketut (2015) and Kanya et al. (2014) shows the effect of liquidity on financial distress. Understanding financial difficulties (financial distress) by Nagar (2016: 15) is: "Financial distress represents the state where firms are facing Financial Difficulties concerning poor cash flows and profitability and is a condition where a company can not meet, or has difficulty paying off, its financial obligations to its creditors, typically due to high fixed costs, illiquid assets or revenues sensitive to economic downturns". Financial distress is a condition that describes the state of a company that is experiencing financial difficulties, meaning that the company is in an unsafe position from the threat of bankruptcy or failure in the company's business. Emrinaldi (2007) states that the most easily seen condition of a company experiencing financial distress is a violation of debt payment commitments accompanied by the omission of dividend payments to investors. Companies experiencing financial distress refer to several criteria, namely: (1) operational losses, (2) core losses, (3) negative retained earnings for the previous two years, and (4) negative working capital for the previous two years (Putra et al, 2020). Bankruptcy prediction serves to guide parties about the company's financial performance whether it experiences financial difficulties or not in the future. A professor at New York University, Edward I. Altman, researched the financial performance of healthy companies. The results of his research are formulated in a mathematical formula called the Altman ZScore formula. This formula uses the components in the financial statements to predict the possibility of a company going bankrupt (Darsono and Ashari, 2005:105).

During a financial crisis, lenders tend to have problems with their liquidity and prefer to lend money to large companies and companies with large collateral in terms of tangible assets. 
Furthermore, during a financial crisis, growths tend to be limited and profitability reduced. It is therefore important to investigate the determinants of leverage during and after a financial crisis. Finally, it has been argued for the need to use a dynamic model of leverage to capture the change in firms' behaviour toward leverage decisions due to the costs associated with adjusting the level of leverage (Miglo, 2011). Hence, we use both the static and dynamic models of leverage to take into account the dynamic nature of the leverage decisions.

$H 2$ : Liquidity affects the financial distress companies.

\section{Effect of Debt Policy on Financial Distress}

Debt policy is a very important decision in the company. Where the debt policy is one part of the company's funding policy. Policies debt is the policy regarding the addition or reduction of corporate debt taken by the management to obtain financing for the company so that it can be used to finance the company's operational activity (Hardiningsih and Oktaviani, 2012). The company's debt policy also functions as a monitoring system for the actions of managers in managing the company. Meanwhile, according to Debt policy, includes research variables, The definition of debt to equity ratio is a financial ratio used to assess debt and company equity (Kasmir, 2014). This ratio is used to determine the total funds provided by the borrower (the creditor) with the company's owner. In other words, how much is the value of each rupiah of the company's capital that is used as debt security. Debt to Asset Ratio is a debt ratio used to measure the ratio between total debt and total assets. In other words, how much the company's assets are financed by debt or how much the company's debt affects asset management (Kasmir, 2010, p. 156). From this definition, we can conclude that the debt to total asset ratio is intended to determine how big the debt portion is in all company-owned assets. According to Martono and Agus (2010, 53), the long-term debt to equity ratio is a ratio that can be used to find out how much business capital is financed by long-term debt. According to experts such as Kashmir and Fahmi, the long-term debt to equity ratio is used to measure companies' level of long-term liabilities with corporate capital.

Debt policy is often measured using a debt ratio which reflects the company's ability to use all of its obligations as indicated by some portion of its own capital used to pay debts. Therefore, the lower the DER (debt to equity ratio), the higher its ability to pay all its obligations. In the end, the increase in debt will affect the level of net income available to shareholders, including dividends to be received. Therefore, a low DER is expected to reduce the level of bankruptcy and financial distress. According to Atmini (2005), the company experiences financial distress if it stops its operations and experiences technical violations in debt and is predicted to experience bankruptcy in the coming period. In the end, the increase in debt will affect the level of net income available to shareholders, including dividends to be received. Therefore, a low DER is expected to reduce the level of bankruptcy and financial distress. Based on the description above, the hypothesis of this research is formulated as follows:

H3: Debt policy affects the company's financial distress.

\section{Methodology}

The quantitative approach is a research method based on the philosophy of positivism, used to examine certain populations or samples, Sugiyono (2018:8). Because this research is in the form of numbers and based on the results of statistical test analysis sourced from the company's annual financial report data. The target population in this study is manufacturing companies that have been listed on the Indonesia Stock Exchange in the period 2014 to 2019. The sampling technique used in this study is purposive sampling. The consideration used by researchers to determine the sample is to determine the various industrial sectors as a sample of companies to be studied by considering the number of financial distress issues in that sector which is following the phenomenon of the problem in this study. The type of data in this study is ratio data, which is data sourced from the company's annual financial statements. The source of data in this study is secondary data. The secondary data in this study is the company's annual financial statements from 2014 to 2019. The company's financial Statement data is obtained from the Indonesia Stock Exchange (IDX) sector data which can be accessed through www.sahamok.net. To obtain the data needed in this study, namely by using the observation method obtained through the websites IDX.co.id and stokok.net. Observations made are indirect, namely by analyzing the company's annual financial statements from the 2014-2019 period. The author analyzed the data using descriptive and verification methods. An invalid and unreliable measuring instrument will provide inaccurate information about the subject's state subject to the test. For this reason, it is necessary to test the validity and reliability of the measuring instrument of this study. The verification analysis in this study uses a statistical test tool, namely the Structural Equation Modeling (SEM) test with the Partial Least Square (PLS) alternative method using SmartPLS 3.0 software. According to Imam Ghozali (2006:1), the Partial Least Square (PLS) method is explained as follows: Variance-based structural equation model (PLS) can describe latent variables (directly immeasurable) and is measured using indicators (manifest variables). The statistical test of this research will evaluate 2 (two) things, namely the Evaluation of Measurement Model (Outer Model) and Evaluation of Structural Model (Inner Model).

\section{Results and Discussion}

\section{Evaluation of Measurement Model (Outer Model) Validity Test}

The definition of validity, according to Sugiyono (2016:177), shows the degree of accuracy between the data that actually occurs on the object and the data collected by researchers to find the validity of an item; we correlate the item score with the total of these items. In this study, there are several stages carried out in testing the validity of a research data, including:

\section{Convergent Validity}

\section{a. Loading Factor}

To test convergent validity, the outer loading value or loading factor is used. A research indicator is declared to meet Convergent Validity in the good category if the outer loading value is $>0.7$. The following is the value of the outer loading of each indicator on the research variable: 


\section{GENERAL MANAGEMENT}

\begin{tabular}{|l|l|l|l|}
\hline Variable & Indicator & Outer Loading & Description \\
\hline \multirow{4}{*}{ Liquidity (X1) } & LIK1 & 0,972 & Valid \\
\cline { 2 - 4 } & LIK2 & 0,964 & Valid \\
\cline { 2 - 4 } & LIK3 & 0,803 & Valid \\
\cline { 2 - 4 } & LIK4 & 0,123 & Invalid \\
\cline { 2 - 4 } & LIK5 & 0,826 & Valid \\
\hline \multirow{5}{*}{ Debt Policy (X2) } & DEBT1 & 0,730 & Valid \\
\cline { 2 - 4 } & DEBT2 & 0,858 & Valid \\
\cline { 2 - 4 } & DEBT2 & 0,727 & Valid \\
\hline Financial Distress (Y) & Y (Z-Score) & 1 & Valid \\
\hline
\end{tabular}

Table 1: Outer Loading

Based on the data presented in table 1 above, it is known that each indicator of the research variable has a value of outer loading $>0.7$. However, it appears that there are still indicators that have an outer loading value of $<0.7$. Therefore, so that the indicators that do not meet the convergent validity requirements cannot be used as research indicators, of the 9 indicators tested, 8 were declared eligible or valid to be used in research and could be used for further analysis.

b. Average Variance Extracted (AVE)

In addition to observing the cross-loading value, Convergent Validity can also be known through other methods, namely by looking at the Average Variant Extracted (AVE) value for each variable, it is required that the value must be $>0.5$ for a good model.

\begin{tabular}{|l|l|}
\hline Variable & AVE \\
\hline Liquidity & 0,800 \\
\hline Debt Policy & 0,599 \\
\hline Financial Distress & 1 \\
\hline
\end{tabular}

Table 2: Average Variant Extracted (AVE)

\section{Discriminant Validity}

This discriminant validity test is carried out to see the correlation between indicators and variables and the correlation between variables.

\section{a. Cross Loading}

In this section, the results of the discriminant validity test will be described. The discriminant validity test uses the crossloading value. An indicator is declared to meet discriminant validity if the value of the cross-loading indicator on the variable is greater when compared to other variables. Cross Loading is done to see the value of the correlation between indicators and research variables. The following is the cross-loading value of each indicator:

\begin{tabular}{|l|l|l|l|}
\hline \multirow{2}{*}{ Indicator } & Variable & \\
\cline { 2 - 4 } & Liquidity (X1) & Debt Policy (X2) & Financial Distress (Y) \\
\hline LIK1 & 0.972 & -0.426 & 0.534 \\
\hline LIK2 & 0.964 & -0.385 & 0.463 \\
\hline LIK3 & 0.803 & -0.277 & 0.328 \\
\hline LIK5 & 0.826 & -0.517 & 0.606 \\
\hline DEBT1 & -0.210 & 0.730 & -0.334 \\
\hline DEBT2 & -0.539 & 0.858 & -0.759 \\
\hline DEBT2 & -0.106 & 0.727 & -0.314 \\
\hline Y (Z-Score) & 0.564 & -0.712 & 1 \\
\hline
\end{tabular}

Table 3: Cross Loading

Based on the data presented in table 3 above, it can be seen that each indicator in the research variable has a greater crossloading value on the variables it forms compared to the crossloading value on other variables. Therefore, based on the results obtained, it can be stated that the indicators used in this study have good discriminant validity in compiling their respective variables. Therefore, it means that the indicator variables in this study have met to be used as indicators in this study.

\section{b. Fornell Larcker Criterion or HTMT}

Similar to the discriminant validity test using the crossloading value, the Fornell Larcker Criterion test is carried out to see the correlation value between the variable and the variable itself and variables with other variables. The following are the Fornell Larcker Criterion values for each variable: 


\section{GENERAL MANAGEMENT}

\begin{tabular}{|l|l|l|l|}
\hline Variable & Liquidity (X1) & Debt Policy (X2) & Financial Distress (Y) \\
\hline Liquidity (X1) & 0.895 & & \\
\hline Debt Policy (X2) & -0.469 & 0.774 & \\
\hline Financial Distress (Y) & 0.564 & -0.712 & 1 \\
\hline
\end{tabular}

Table 4: Fornell Larcker Criterion

Based on the data presented in table 4, above, it can be seen that each indicator in the research variable has a Fornell Larcker Criterion value that is greater in the variable itself compared to the Fornell Larcker Criterion value between other variables. Therefore, based on the results obtained, it can be stated that the variables used in this study have good discriminant validity.

\section{Reliability Test}

After all the Validity Test stages have been passed, it means that all indicators used in this study are valid to be able to measure the variables of this research; the next step is to perform the Reliability Test stage. That is to ensure that the research data that has been previously tested is reliable or not. In this study, the reliability test was carried out in two stages, namely as follows:

\section{a. Composite Reliability}

The value that indicates that the research data is reliable where the value that must be shown in this test is above $(>) 0.7$.

\begin{tabular}{|l|l|}
\hline Variable & Composite Reliability \\
\hline X1-Liquidity & 0.941 \\
\hline X2-Debt Policy & 0.817 \\
\hline Y-Financial Distress & 1 \\
\hline
\end{tabular}

Table 5: Composite Reliability

Based on the data presented in table 5 above, it can be seen that the composite reliability value of all research variables is > 0.7. These results indicate that each variable has met composite reliability, so it can be concluded that all variables have a high level of reliability.

\section{b. Cronbach's Alpha}

Similar to the Composite Reliability value, the Cronbach's
Alpha test must also show a number above (>) 0.7. The reliability test with the composite reliability above can be strengthened by using the Cronbach alpha value. A variable can be declared reliable or fulfills Cronbach alpha if it has a Cronbach alpha value $>0.7$. The following is the Cronbach alpha value of each variable. It means that each indicator in this study can measure the variables so that this research becomes reliable.

\begin{tabular}{|l|l|}
\hline Variable & Cronbach's Alpha \\
\hline Liquidity & 0.917 \\
\hline Debt Policy & 0.755 \\
\hline Financial Distress & 1 \\
\hline
\end{tabular}

Table 6: Cronbach's Alpha

\section{Results And Discussion}

\section{Liquidity relationship d ith Debt Policy}

Based on the results of hypothesis testing conducted in the study variables Liquidity $d$ ith Debt Policy where liquidity and debt policies as a variable independent (exogenous) is a liquidity ratio influences debt policy. Where the $\mathrm{P}$-Value value in the first hypothesis $(\mathrm{H} 1)$ is 0.00 , it means that it is below 0.05 so that the hypothesis is accepted. And the T-Statistic value is 6.897 , and the beta coefficient value is negative (-) of 0.469 . Value T-Statistic above $(>) 1.96$ and path coefficient $<0$ means that the liquidity variables have a significant impact negatively on the debt policy. Liquidity is a tool to assess a company's financial performance by measuring its ability to meet its shortterm obligations. One of the liquidity ratios is the current ratio (CR), which compares current assets and current liabilities (Munawir, 2012: 72). According to Ozkan (2001), liquidity affects debt policy because current assets provide convenience in repaying debt.

\section{Relationship between Liquidity and Financial Distress}

Based on the results of hypothesis testing conducted in the study variables Liquidity on Financial Distress where liquidity as an independent variable (exogenous) and financial distress as the dependent (endogenous) is a liquidity ratio that influences financial distress. The value of $\mathrm{i} P$-Value in the second hypothesis $\left(\mathrm{H}_{2}\right)$ is 0.00 , meaning it is below 0.05 so that the hypothesis is accepted. And the T-Statistic value is 5.408 , and the beta coefficient value is positive $(+)$ of 0,295 Value TStatistic above $(>) 1.96$ and path coefficient $>0$ means that the liquidity variables have a significant impact positively on the financial distress. Companies are increasingly illiquid and will be able to pay off debt and not be piled so that things that can positively signal outsiders that the company can pay off the current debt and avoid the problem of finance. Research History who do I Gusti and Ni Ketut (2015) and Kanya et al. (2014) menunjukka $n$ the influence of liquidity to financial distress. 


\section{GENERAL MANAGEMENT}

\section{Relationship between Debt Policy and Financial Distress}

Based on the results of hypothesis testing conducted in the study variables Debt Policy on Financial Distress, the debt policy as an independent variable (exogenous) and Financial distress as a variable dependent (endogenous) is a debt policy influences financial distress. The value of i P-Value in the third hypothesis $(\mathrm{H} 3)$ is 0.00 , meaning it is below 0.05 so that the hypothesis is accepted. And the T-Statistic value is 10.272, and the beta coefficient value is negative (-) of, 573 . Value TStatistic above (>) 1.96 and path coefficient $<0$ means the variable debt policies have a significant impact on financial distress. According to Atmini (2005), companies are experiencing financial distress if the company ceases operations and experienced a technical foul in debt and is expected to have a bankruptcy in the period that will come. In the end, the increase in debt will affect the level of net income available to shareholders, including dividends to be received. Therefore, a low DER is expected to reduce the level of bankruptcy and financial distress.

\section{Conclusion}

This study aims to examine whether liquidity and debt policy have an effect on financial distress (empirical studies on manufacturing companies in various industrial sectors on the 2014-2019 BEI). Liquidity has been proven to have a significant positive effect on financial distress, the higher the liquidity of a company, the more able to pay off the company's debt and it will not accumulate so that it can give a positive signal to outsiders that the company can pay off current debt and avoid financial difficulties. The policy proved to have a significant negative effect on financial distress. In the end, an increase in debt will affect the level of net income available to shareholders, including dividends to be received. A low DER is expected to reduce the level of bankruptcy and financial distress. So that a good corporate debt policy will also affect the occurrence of financial distress. The company's liquidity is proven to have a significant negative effect on debt policy. Liquidity affects debt policy because current assets provide convenience in paying off debt. Theoretically, the firm should be able to control the level of debt to equity. These results suggest that managers need to make some adjustments to the firm's liquidity level to meet their needs for debt and equity financing.

\section{References}

[1] Akoto, R. K., \& Awunyo-Vitor, D. (2013). What Determines the Debt Policy of Listed Manufacturing Firms in Ghana? International Business Research, 7(1). doi:10.5539/ibr.v7n1p42

[2] Brigham, E F, dan Houston, J F. (2006). Dasar- Dasar Manajemen Keuangan. Buku Kedua. Edisi Kesepuluh. Jakarta: Penerbit Salemba Empat.

[3] Bringham dan Gapenski (1996). Intermediate Financial Management, Fifth Edition, New York: The Dryden Press.
[4] Chairiri, A dan Ghozali, I. (2007). Teori Akuntansi. Badan Penerbit Universitas Diponegoro: Semarang.

[5] Gibson, J.L. (1997). Manajemen. (Alih Bahasa: Zuhad Ichyandin). Jakarta: Erlangga Hardiningsih, P dan Rachmawati, O. (2012). Determinan kebijakan hutang, dalam agency theory dan pecking order theory. Dinamika akuntansi keuangan dan perbankan,1(1), $11-24$

[6] Hanifah, O. E. (2013). Analisis struktur corporate governance dan financial indicators terhadap kondisi financial distress. Jurnal Akuntansi Universitas Diponegoro, 2(2), 1-15.

[7] Indahningrum dan Handayani. (2009). Pengaruh Kepemilikan Manajerial, Kepemilikan Institusional, Deviden, Pertumbuhan Perusahaan, Free Cash Flow dan Profitabilitas terhadap Kebijakan Hutang Perusahaan, Jurnal Bisnis dan Akuntansi 11(3),189-207.

[8] Murni, S dan Andriana. (2007). Pengaruh Insider Ownership, Institusional investor, Deviden Payments, dan Firm Growth terhadap Kebijakan Hutang Perusahaan. Jurnal Akuntansi dan Bisnis, 7(1), 15-24.

[9] Munawir. (2004). Analisa Laporan Keuangan. Penerbit Liberty: Yogyakarta.

[10] Miglo, A. (2011). Trade-Off, Pecking Order, Signaling, and Market Timing Models. Capital Structure and Corporate Financing Decisions, 171-189. doi:10.1002/9781118266250.ch10

[11] Ozkan, A. (2001). Determinants of Capital Structure and Adjustment to Long Run Target: Evidence From UK Company Panel Data. Journal of Business Finance <html_ent Glyph=“@amp;" Ascii=“\&amp;"/> Accounting, 28(1-2), 175-198. doi:10.1111/1468-5957.00370

[12] Paydar dan Bardai. (2012). Leverage Behavior of Malaysian Manufacturing Companies A Case Observation of The Industrial Sector's Companies in Bursa Malaysia. International Research Journal of Finance and Economics, 90, (54-65).

[13] Platt, H. D., \& Platt, M. B. (2006). Understanding differences between financial distress and bankruptcy. Review of Applied Economics, 2(2), 141-157.

[14] Putra, I.M.W., Kawisana, P.G.W.P (2020).The Influence Of Company Size, Financial Distress, Kap Reputation On Going Concern Audit Opinion Of Manufacturing Companies From BEI. International Journal of Environmental, Sustainability, and Social Science, 1(2), 57-61. https://doi.org/10.38142/ijesss.v1i2.15

[15] Ramlall. (2009). Determinants of Capital StructureAmong NonQuoted Mauritian Firms Under Specificity of Leverage: Looking for A Modified Pecking Order Theory. International Research Journal of Finance and Economics 31 (31), 83-92.

[16] Saidi. (2004). Faktor-Faktor yang Memengaruhi Struktur Modal pada Perusahaan Manufaktur Go Public di BEJ Tahun 1997 2002. Jurnal Bisnis dan Ekonomi, II.

[17] Sugiyono. (2018). Metode Penelitian Bisnis. Pusat Bahasa Depdiknas: Bandung

[18] Suharmadi, Suripto,(2021)."Effect Of Liquidity, Productivity and Firm Size On Bond Ranking". International Journal of Environmental, Sustainability, and Social Sciences, 2(2), 7988.https://doi.org/10.38142/ijesss.v2i2.78 